\title{
Fostering caring in undergraduate nursing students: An integrative review
}

\author{
Sandra G. Nadelson ${ }^{* 1}$, Tory Zigmond ${ }^{2}$, Louis Nadelson ${ }^{3}$, Morgan Scadden ${ }^{1}$, Chelsea Collins ${ }^{4}$ \\ ${ }^{1}$ Nursing Program, Utah State University, Logan, USA \\ ${ }^{2}$ Surgical Services, St. Luke's Regional Medical Center Boise, USA \\ ${ }^{3}$ College of Education and Human Services, Utah State University, Logan, Utah, USA \\ ${ }^{4}$ Emergency Room and Trauma Center, University of Colorado Hospital, Denver, USA
}

Received: March 9, 2016

DOI: $10.5430 /$ jnep.v6n11p7
Accepted: May 24, 2016

Online Published: June 21, 2016

URL: http://dx.doi.org/10.5430/jnep.v6n11p7

\begin{abstract}
Background: Assuring undergraduate nursing students are caring and compassionate is an important goal of nursing education programs. Some research has been conducted to examine interventions to enhance nursing students' levels of caring.

Methods: We conducted an integrative review of caring research and found fifteen articles reporting educational interventions designed to enhance caring among undergraduate pre-licensure nursing students. We reviewed each for how caring was taught and the student outcomes.

Results: Our analysis indicates that caring can be taught to nursing students. Effective educational interventions included engaging students in authentic conditions that required them to provide care, reflection on the care they provided, and faculty members role modeling caring behaviors.

Conclusions: Implications for nursing educators is that their curricular and instructional approaches are critical to enhancing nursing students' levels of caring.
\end{abstract}

Key Words: Caring, Nursing education, Reflection, Simulation, Undergraduate, Service learning

\section{INTRODUCTION}

\subsection{Changes in health care relating to caring}

There is a general perception of nursing as being a "caring" profession - an occupation that requires the professionals to exhibit and convey caring. While nursing students may exhibit higher levels of caring than their peers preparing for other professions, ${ }^{[1]}$ they are arguably more likely to be expected to exhibit great levels of caring behaviors in their careers. While caring can have multiple meanings, for our research we are considering caring with respect to levels to which nurses exhibit positive empathy and compassion for those that they work with.
Nursing needs caring individuals. Graduating people who interact with others in an empathetic and compassionate manner is mandatory for nursing to maintain the image of being a caring profession. Not only nursing's reputation at stake, but having caring nurses does have an economic impact in health care. The stakes for assuring healthcare workers express care for others continues to rise as healthcare organizations are now receiving payments for medical care based partially on the Hospital Consumer Assessment of Healthcare Providers and Systems (HCAHPS) survey results. ${ }^{[2]}$ The primary purpose of the survey is to measure consumers' perceptions of care that they received at a hospital. As Wysong and Driver

*Correspondence: Sandra G. Nadelson; Email: sandie.nadelson@usu.edu; Address: 2695 Old Main Hill, Logan Utah, USA. 
report, patients' satisfaction with hospital care is based on their perception of nursing caring behaviors and not solely on the tasks or procedures. ${ }^{[3]}$ Consequently, several HCAHPS survey items are specifically designed to assess consumers' views of the care provided by nurses and the caring behaviors exhibited by the nurses. Thus, a strong climate and professional acts of caring within a health care organization are no longer an amenity, but have become essential aspects of healthcare organizations' success. ${ }^{[4,5]}$

Boykin, Schoenhofer and Valentine suggest that there is a need to enhance the culture of caring in the current healthcare environment. ${ }^{[5]}$ There are multiple perceptions of caring ${ }^{[6]}$ but there is general consensus that care is based on communications and relationship building among those being cared for and the responding healthcare professionals, including nurses. ${ }^{[7,8]}$ Therefore, consistent with Duffy, we maintain that the success of healthcare organizations frequently relies on nurses providing a range of effective care (both physical and emotional) for patients. ${ }^{[9]}$ The critical nature of nurses engaging in caring for the success of healthcare organizations provides justification for examining the research on developing levels of caring in nurses.

Recent research findings indicate the patients are reporting diminished levels of caring by nurses. ${ }^{[10]}$ As a result, nursing educators and healthcare organizations are supporting efforts that foster caring behaviors of nurses and are working to assure sustained and perceptible cultures of caring for current and future nurses. With the call to enhance the levels of caring among current and future nurses, educators are being asked to develop new and effective pedagogies that teach nurses about caring. ${ }^{[10]}$ However, helping students studying to be nurses (or other professionals) develop higher levels of caring is not a trivial task. ${ }^{[1]}$ Nursing educators need a clear and consistent understanding of what caring is, what skills and abilities are needed to be successful at caring, and how to assure nursing students learn to be effective at caring. As mentioned previously, the foundational components for caring that are required by today's nursing graduates include strong communication and relationship skills. ${ }^{[7]}$ Unfortunately, not all nursing students graduate with these skills and are not always seen as caring people. As Labrague reports assessment of nursing student caring by the patients they interacted with indicated only moderate levels of caring. ${ }^{[12]}$ More alarmingly, there is evidence to indicate that some nursing students' levels of caring actually decrease while they are enrolled in nursing preparation programs ${ }^{[13]}$ and may also be found to be lower among older students. ${ }^{[14]}$ We maintain that the potential for caring to negatively shift with nursing students is justification for including interventions that attend to students' levels of caring as part of their preparation programs.

Since graduating nursing students with the ability to provide healing care to others is an essential component of our profession, being able to identify interventions that foster perceptions of caring is important to enhancing our educational processes and profession. Strong cases for the need for nurses to be effective at caring led us to ask, what are some of the best evidence practices associated with preparing nursing students to be effective and proficient at caring? To answer our question and provide an understanding of the state of the art for teaching caring behaviors, we did an integrative review of literature, examining extant studies of developing levels of caring in nursing students. We begin our report by discussing and reviewing the literature related to nursing student growth and efforts to increase students' levels of caring. Specifically, we explore trends in nursing student development, a deeper examining of caring as a construct, and the role of nursing programs in fostering student development of caring. Our review of the literature is followed by a presentation of the process and results of our integrative review of the literature, focusing on teaching caring to undergraduate nursing students, and a discussion of findings and some potential implications for nursing education.

\subsection{The literature}

The focus of post-secondary education has been evolving over the last decade as the broader liberal studies focus of undergraduate programs has been shifting to a greater focus on job skills and career preparation. ${ }^{[15-17]}$ As a result, the number of programs that emphasized practical applications specific to careers or professions have been increasing while fewer students are enrolling in liberal arts courses. ${ }^{[17-19]}$ The movement toward greater emphasis on career preparation in higher education has led to shifts in policy and funding. For example, "fast track programs" of education to job placement have led to modifications in course offerings and degree requirements. ${ }^{[18]}$ Often, the shift toward the focus on career preparation in degree programs have led to the elimination of non-technical, liberal arts course in the programs to make space for courses focused on career content. ${ }^{[17]}$ Consequently, in many nursing degree programs philosophy and other humanity courses, courses that commonly include opportunities to learn about issues associated with the human condition including caring for others, are being replaced by courses focused on the "hard sciences" or technical content. The shift has led nursing educators to consider the goal of nursing preparation programs as the process of instilling information into students' minds rather than developing well-rounded graduates. ${ }^{[20]}$ However, while nursing faculty recognize the importance of teaching nursing 
students to be more caring many admit that they are unaware of how to effectively teach caring. ${ }^{[21]}$

Most educators do believe that teaching values, such as accountability and professionalism, is an important goal of faculty members, but also recognize that teaching values may not be an explicit area of focus. ${ }^{[22,23]}$ In addition, how the teaching of values, including caring, is included within the higher education curriculum is not well studied or understood. ${ }^{[22]}$ Teaching values, such as caring, is often a "hidden curriculum" limiting opportunities to effectively examine or even acknowledge the curriculum. ${ }^{[24,25]}$ Even when the teaching of values is more explicit, what should be taught and how values are taught are not always agreed upon and which can leave students with an unclear understanding of their values upon graduation. ${ }^{[26]}$

\subsection{Caring}

Caring is a broad, but not well defined or understood value or construct. ${ }^{[27]}$ We maintain that most people readily identify caring people as those how act in an empathetic manner or as individuals who connect with people in a dynamic way. Yet, as we discussed previously it is not an easy task is to clearly define the array of actions and characteristics associated with caring. In an attempt to describe caring, Larrivee explains that caring consists of four fundamental aspects: respect for others, authenticity, thoughtfulness, and emotional integrity. ${ }^{[28]}$ Watson adds that caring includes ten processes including creating a healing environment, being creative in using oneself, being supportive, and being authentic. ${ }^{[29]}$ Building on Watsons' work, Porr and Egan suggest that caring in nursing involves intentionality, relationships, and responsiveness. ${ }^{[30]}$ For the purposes of our study, we maintain that caring involves a connection between two or more individuals which is perceived as building and supporting an environment of physical and emotional wellbeing.

Certainly, positive and supportive interactions that result in caring environments are conditions which workers (particularly leadership) in healthcare organizations want and need to foster. As mentioned, how caring is fostered or developed is not well defined. Regardless, many people believe that caring is an attribute that can (and should) be taught and therefore, maintain that individuals' levels of caring can enhanced through educational interventions. ${ }^{[7]}$ However, little research has been done to identify what are the most effective methods of enhancing individuals' level of caring. ${ }^{[31]}$ Of interest to us in particular is the outcomes of research on educational interventions designed to enhance nursing students' levels of caring. Our interest led us to consider an integrative search of literature to compile not only quantitative data to determine effect sizes but also a list of evidence

Published by Sciedu Press based practices that have been documented to be effective at enhancing nursing students' levels of caring.

\section{MethodS}

To answer our research question we determined there was justification for examining reports of educational interventions designed to enhance nursing students' capacity to care for others. We chose to do an integrative search of the literature rather than a systematic review due to the challenges associated with identifying appropriate studies. For example, the keyword "caring" has two different primary meanings in nursing. Thus, many reports of teaching about "caring" in nursing refer to the process of attending to patients' physical needs (e.g., engaging in the steps of medical procedures) rather than "caring" in terms of attending to patients' emotional wellbeing. To assure our research was meaningful, fruitful, and timely we determined the more strategic approach of an integrative search to be the most appropriate method for securing the literature for our study evidence based practices to teaching caring. ${ }^{[32]}$ As Whittemore and Knalf argue, integrative reviews allow for the acceptance of a broader range of literature that is reflective of evidence based practice and is therefore a method that is likely to result in a more comprehensive consideration of the relevant literature. ${ }^{[32]}$

We began our integrative search of the literature by identifying the databases we thought would be most likely to contain a useable collection of nursing education research reports. We focused our search on the literature contained in the EBSCO database (which includes CINHAL) and the Google Scholar database because of the comprehensive inclusion of a wide range of educational research studies, including nursing education. The key terms we used in our searches included "research", "caring", "nursing" and "student". Articles were excluded written in English. The time period for publications that we used for our search was January 2008 to February 2016.

The result of our keyword search was several hundred articles. To identify those aligned with our research we first examined the title of the articles, which allowed us to immediately filter many articles that were focused on care in terms of medical procedures our focused on working licensed nurses, which we removed from consideration. We next read the abstracts of the remaining articles, which facilitated further filtering for educational interventions. Thus, we removed from our potential list of articles to review any reports that were not directly associated with interventions to foster levels of emotional caring with undergraduate pre-licensure nursing students. While certainly of value, we did not include case studies of very small numbers of students (i.e., less than five 
students), as the generalizability of these studies is extremely limited. In our final round of coding, we read the remaining articles to assure they were empirically based intervention research studies and not simply reports of ideas for enhancing caring in undergraduate nursing students.

Our search methods resulted in a collection of fifteen articles (see Table 1) reporting evidence of interventions designed to enhance nursing students' levels of caring which we considered for our analysis. It is upon these fifteen articles we report our results. Research methods used in these studies include qualitative, quantitative, mixed methods, and systematic literature review (see Table 1). However, the majority of reports that met our research criteria used qualitative research methods. Overall, the diversity of research provided a rich data set for examining effective ways of enhancing undergraduate nursing students' level of caring.

\section{RESUlts}

\subsection{How caring is taught}

The articles we used in our analysis reflected the reported the complexity of teaching, learning and researching caring. ${ }^{[33]}$ The collection revealed a wide range of how caring is being taught to student. Many interventions engaged students in authentic learning experiences that required them to be caring. These learning experiences were either simulations of the kinds of situations nurses encounter as professions of were scaffolded high impact low risk situations. Thus, authentic emersion interventions involved either replicating professional situations or engaging students in professional situations with high levels of support and tolerance of learning and growth.

In our analysis of the use of simulation and case studies interventions to teach caring we found approached that positioned students in situations aligned with those they are likely to encounter as professionals with the expectation that students would develop their sense of what it is like to have a medical condition or treat others with a condition. ${ }^{[25,34,36-38]}$ Similarly, some interventions involved students engaging in role modeling opportunities as nurses and patients and then reflecting on the levels of perceive caring provide and received which was documented to successfully enhance the levels of caring in undergraduate nursing students. ${ }^{[39-41]}$ Taking a different approached some successful interventions involved engaging students in service learning experiences which allowed the students to effectively interact with those requiring care. ${ }^{[42,43]}$ The service learning interactions afforded students the opportunity experience caring for others in authentic situations which led them to develop a deeper sense of caring. ${ }^{[42]}$ Comparable to service learning, when students took part in studying abroad opportunities (e.g., Nurses Without Borders), they were effectively positioned to be exposed to different world views which led the students to deeper levels of compassion for diversity of people living in challenging conditions. ${ }^{[44]}$

Within the diversity of instructional approaches, we identified a pattern of involving the students in low risk high engagement activities. Further the experiences integrated opportunities for the students reflect on their caring experiences. Thus, common to the interventions were relatively safe opportunities for students to engage in providing care to others and the conditions for the students to think about and process how they provided care, what was effective, and what they might do in the future.

\subsection{Student outcomes}

In our analysis of the reports in our data set we found that most of the interventions appeared to enhance students' ability to understand the experience of other people and respond in a caring manner (see Table 1). We interpret our findings to suggest that engaging students in situations that are representative of or aligned with caring environments leads to higher levels of caring among the students. Regardless of the environment, our analysis of the outcomes of the considered studies does suggest that using techniques such as role modeling or community engagement does seem to be an effective manner of teaching nursing students how to recognize different world-views and respond with the appropriate provision of caring. [40]

Another consistency that we found across most studies was students' reflection on their actions and the situations related to caring. In the research studies that met our review criteria we found that the caring education interventions involved encouraging students to use reflection and discussion to process the experiences they had. ${ }^{[27,38,43,46]}$ Some of the interventions we examined included the use of written reflections to engage the students in thinking about their caring while other interventions used oral approaches to providing students' to develop deeper understanding of their caring experiences and work they need to do to improve their ability to be a caring individual. ${ }^{[36,42,46]}$ The use of reflection to enhance student learning of caring is well documented in nursing educational literature. ${ }^{[47]}$ Thus, our review of the retained studies is consistent with previous research and theory on enhancing nursing students' levels of caring learning and performance. $^{[33]}$ 
Table 1. Synthesis of Research Reports used in the Review

\begin{tabular}{|c|c|c|c|c|}
\hline Citation & Study design & Intervention & Findings & Implications \\
\hline $\begin{array}{l}\text { Adamski, Parsons, } \\
\text { \& Hooper }{ }^{[34]}\end{array}$ & Mixed methods & $\begin{array}{l}\text { Experienced nurses shared stories of } \\
\text { caring with undergraduates. }\end{array}$ & $\begin{array}{l}\text { Small positive effect on } \\
\text { students' levels of caring } \\
\text { through sharing of stories. }\end{array}$ & $\begin{array}{l}\text { Use of narrative pedagogy to demonstrate } \\
\text { caring behaviors to enhances student caring. }\end{array}$ \\
\hline $\begin{array}{l}\text { Chan, Mok, } \\
\text { Po-ying, \& } \\
\text { Man-chun }{ }^{[35]}\end{array}$ & Mixed methods & $\begin{array}{l}\text { Four interdisciplinary seminars were } \\
\text { conducted and each student group } \\
\text { participated in two sessions that lasted } \\
\text { for about } 3 \text { hours. }\end{array}$ & $\begin{array}{l}\text { Results indicate caring was } \\
\text { fostered through seminars. }\end{array}$ & $\begin{array}{l}\text { Interdisciplinary education can be used to } \\
\text { seminars to improve caring. }\end{array}$ \\
\hline $\begin{array}{l}\text { Curtis \& } \\
\text { Jensen }^{[39]}\end{array}$ & Qualitative & $\begin{array}{l}\text { Used "confluent education” techniques } \\
\text { in community health: such as } \\
\text { contemporary literature, film, guest } \\
\text { speakers, field trips, and clinical } \\
\text { experiences. }\end{array}$ & $\begin{array}{l}\text { Caring fostered through } \\
\text { educational interventions. }\end{array}$ & $\begin{array}{l}\text { Use integrative learning strategies to develop } \\
\text { and support caring, empathy, and cultural } \\
\text { awareness. }\end{array}$ \\
\hline $\begin{array}{l}\text { Drumm \& } \\
\text { Chase }^{[40]}\end{array}$ & Qualitative & $\begin{array}{l}\text { The principal investigator researched the } \\
\text { lived experience of students learning } \\
\text { caring in a college of nursing grounded in } \\
\text { a caring philosophy. }\end{array}$ & $\begin{array}{l}\text { Caring fostered as seen as } \\
\text { more confidence and deeper } \\
\text { understanding of caring. }\end{array}$ & $\begin{array}{l}\text { Faculty should role-model caring attitudes } \\
\text { enhance the learning environment for } \\
\text { students. }\end{array}$ \\
\hline Eggenberger ${ }^{[36]}$ & Qualitative & $\begin{array}{l}\text { Using a caring teaching framework of } \\
\text { briefing, encountering, and debriefing to } \\
\text { structure a simulated experience } \\
\text { grounded in a caring nursing situation. }\end{array}$ & $\begin{array}{l}\text { Caring fostered through } \\
\text { simulation experience. }\end{array}$ & $\begin{array}{l}\text { Simulation can be used as a method to teach } \\
\text { and evaluate caring in nursing in a variety of } \\
\text { ways. }\end{array}$ \\
\hline Gonzalez et al. ${ }^{[31]}$ & $\begin{array}{l}\text { Meta-synthesis; } \\
\text { qualitative } \\
\text { literature review }\end{array}$ & Review of literature & $\begin{array}{l}\text { Students gained caring and } \\
\text { empathy through various } \\
\text { experiences including } \\
\text { simulation. }\end{array}$ & $\begin{array}{l}\text { Educators should include humanistic } \\
\text { processes in simulation learning. }\end{array}$ \\
\hline $\begin{array}{l}\text { Jukema, van } \\
\text { Veelan, \& } \\
\text { Vonk }^{[27]}\end{array}$ & $\begin{array}{l}\text { Reflective case } \\
\text { study }\end{array}$ & $\begin{array}{l}\text { The students were given a framework for } \\
\text { providing patient care which had three } \\
\text { domains: "person-centredness, } \\
\text { professional role and specific nursing } \\
\text { competencies." }\end{array}$ & $\begin{array}{l}\text { Caring enhanced through } \\
\text { providing a framework and } \\
\text { reflection. }\end{array}$ & $\begin{array}{l}\text { The use of reflection in nursing education } \\
\text { related to caring seems particularly helpful. }\end{array}$ \\
\hline $\begin{array}{l}\text { Letcher \& } \\
\text { Nelson }^{[41]}\end{array}$ & Quantitative & $\begin{array}{l}\text { Started culture of caring on two inpatient } \\
\text { floors. }\end{array}$ & $\begin{array}{l}\text { The Community of Care } \\
\text { model enhanced student } \\
\text { caring. }\end{array}$ & $\begin{array}{l}\text { Using the Community of Care model can help } \\
\text { build a better environment for caring. }\end{array}$ \\
\hline $\begin{array}{l}\text { Ozolins, } \\
\text { Elmqvist \& } \\
\text { Hörberg }{ }^{[42]}\end{array}$ & Qualitative & $\begin{array}{l}\text { Interactions within a student run clinic } \\
\text { which included group reflection. }\end{array}$ & $\begin{array}{l}\text { The experiences in the clinic } \\
\text { helped deepen and broaden the } \\
\text { students' understanding of } \\
\text { caring science in practice. }\end{array}$ & $\begin{array}{l}\text { Faculty should develop additional clinical } \\
\text { opportunities for students to work with people } \\
\text { and be able to apply reflective caring } \\
\text { approaches. }\end{array}$ \\
\hline McGarry $^{[45]}$ & Qualitative & $\begin{array}{l}\text { "Clear caring values” were used with } \\
\text { students. }\end{array}$ & $\begin{array}{l}\text { Indications caring was } \\
\text { fostered. }\end{array}$ & $\begin{array}{l}\text { Early encounters and observations within the } \\
\text { practice setting should be used to challenge } \\
\text { these ideals and improved caring. }\end{array}$ \\
\hline $\begin{array}{l}\text { Minnesota } \\
\text { Bachelor } \\
\text { Psychomotor } \\
\text { Skills Faculty } \\
\text { Group }^{[37]}\end{array}$ & Quantitative & $\begin{array}{l}\text { Students took a blood pressure and were } \\
\text { evaluated on their performance. Then } \\
\text { they did reading, watched a video. Plus, } \\
\text { instructors provided caring content in } \\
\text { various courses through lecture, } \\
\text { demonstration, role-playing, and } \\
\text { observational learning. }\end{array}$ & $\begin{array}{l}\text { Simulation scenarios and other } \\
\text { educational activities seemed } \\
\text { to influence students' levels of } \\
\text { caring as they took people's } \\
\text { blood pressure. }\end{array}$ & $\begin{array}{l}\text { Simulation, videos, and content within course } \\
\text { including lecture, demonstration, } \\
\text { role-playing, and observational learning can } \\
\text { influence students' levels of caring. }\end{array}$ \\
\hline $\begin{array}{l}\text { Panowsky \& } \\
\text { Diaz }^{[38]}\end{array}$ & Qualitative & $\begin{array}{l}\text { Students were asked to wear an ostomy } \\
\text { bag and/or wet adult diapers as } \\
\text { simulation experience in a community } \\
\text { health course. }\end{array}$ & $\begin{array}{l}\text { Caring was fostered through } \\
\text { the simulated experience. }\end{array}$ & $\begin{array}{l}\text { Students' caring can be fostered through } \\
\text { experiencing what it is like to be a patient. }\end{array}$ \\
\hline Schofield et al. ${ }^{[43]}$ & Qualitative & Service learning and reflection. & $\begin{array}{l}\text { Service learning with } \\
\text { reflection fostered caring }\end{array}$ & $\begin{array}{l}\text { Service learning can have an impact on } \\
\text { student caring when combined with reflection. }\end{array}$ \\
\hline $\begin{array}{l}\text { Stewart Hegedus } \\
\text { et al. }{ }^{[43]}\end{array}$ & Case study & $\begin{array}{l}\text { Students participated in a study abroad } \\
\text { and sharing of stories. }\end{array}$ & $\begin{array}{l}\text { Students' caring was } \\
\text { enhanced. }\end{array}$ & $\begin{array}{l}\text { Study abroad experiences can be used to } \\
\text { enhance students caring and connections with } \\
\text { people. }\end{array}$ \\
\hline $\begin{array}{l}\text { Waugh \& } \\
\text { Donaldson }^{[46]}\end{array}$ & Qualitative & $\begin{array}{l}\text { Nursing students were given stories } \\
\text { about peer caring in audio or digital } \\
\text { format about caring and reflected on the } \\
\text { stories. }\end{array}$ & $\begin{array}{l}\text { Stories and reflection } \\
\text { enhanced caring. }\end{array}$ & $\begin{array}{l}\text { Stories can be used to enhance compassionate } \\
\text { care when reflection is include in the process. }\end{array}$ \\
\hline
\end{tabular}

In summary, our analysis of the findings of the fifteen articles in our data set consistently indicate that caring can be fostered in undergraduate students. While the instructional approaches varied between the studies we examined, we found consistent opportunities for students to reflect on their engagement in caring to develop a better understanding of 
their influence on others' needs to be cared for.

\section{DisCUSSION AND IMPLICATIONS}

The goal of our research was to determine what approaches have been effective for teaching nursing students caring and synthesize an evidence based recommendation for increasing nursing students' levels of caring. While the majority of articles that met the criteria of our integrative review criteria were qualitative and/or descriptive in nature, we found consistency in the caring education interventions and the student outcomes. All of the studies indicated that caring can effectively be taught to students. None of the methods used in the studies we examined indicated that attempts to foster caring can be detrimental to students. Overall, our review of reports indicates that caring can be enhanced through deliberate nursing education interventions. Thus, it seems reasonable to conclude that nursing programs should encourage and implement activities that engage students in activities that broaden their awareness of themselves as caregivers and the needs of the people they care for as effective ways of increasing the students' level of caring.

\subsection{Limitations and future research}

There were some limits to our study. First, not all of the interventions in the studies we examined were well defined requiring us to infer the interventions based on multiple parts of the reports. Several of the reports indicated that the student engaged in a variety of caring instructional activities which limited the ability to determine if a single instructional element, a combination of elements, or all elements were responsible for increasing the students level of caring. Future research on caring interventions should be more strategically planned to and reported to provide a clear delineation of instructional approach and corresponding student outcomes

A second limitation of our research was the lack of consistency in the measures of caring used in the examined reports to assess the students' levels of caring. Our examination of the measures revealed a wide variation or a lack of explicit identification of the measure. While the integrative review process allows researchers to tolerate the ambiguity and variation to expose best practices, ${ }^{[32]}$ the situations does suggest a need for consistency in assessment of caring in future research. The use of a common tool for measuring levels of could clarify the impact of a range of caring instruction intervention.

Two final limitations of our research was the cumbersome process of our search and the limited number of studies we were able to locate that reported and measured an intervention designed to assess nursing students' levels of caring. Because of the need to sort through so many articles about caring, there is a possibility that articles which should have been included were overlooked. In addition, our numbers of included articles were small. While our integrative approach resulted in fifteen studies for consideration, our research could have benefitted from a greater number of empirically documented caring interventions. Thus, future research should be considered to attend to this gap in the literature.

\subsection{Implications for practice}

The curriculum and instruction choices by faculty members teaching in nursing preparation programs can effectively enhance student levels of caring. Through our integrative review we have found three evidence based practices for enhancing nursing students level of caring. First, we found placing students in authentic situations (including simulations of situations) where they engage in caring behaviors can be positive experiences for students in terms of building their long-term ability to be effective at caring for others. Second, having students reflect on the caring they provided during patient interactions appears effective in enhancing nurse students' levels of caring. Thus, prior to, during, and after engaging in the authentic caring situations having students explicitly think about their levels of caring can enhance their capacity to care for others. The reflection may take place through group discussions about caring, seminars on components of caring, using a caring behavior self-assessment tool, and journaling about caring. The third evidence based activity that we identified as effectives for enhancing students' levels of caring involves nursing faculty members positively role modeling caring. By role modeling caring faculty members can exhibit caring of the students and caring with the students while engaging in authentic experiences which allows students to observe models of caring provided by nursing professionals.

Thus, when considering evidence based practices for teaching nursing students to be more caring, faculty members may want to consider a combination of approaches from authentic situations, reflection, and role modeling. Regardless of the combination used to support student caring development it is critical that nursing faculty members keep in mind that their curricular and instructional approaches can (and likely will) influence their nursing students' short and long-term levels of caring.

\section{Conclusions}

Teaching caring as part of nursing preparation programs is important to student development and the success of healthcare organizations where they are going to work. There is no single intervention that easily promotes nursing student 
caring development, there are some criteria for effective interventions that we evidence based. Engaging students in low risk high return activities such as simulation and then reflecting about the caring that took place in the situations appears to be essential for teaching caring. We have encounter faculty

\section{REFERENCES}

[1] Nadelson SG, Nadelson LS, Osguthorpe R. Students as carers across disciplines: Quantifying student caring in high education. The Researcher. 2010; 23(1): 59-73.

[2] Centers for Medicare \& Medicaid Services Hospital Consumer Assessment of Healthcare Providers and Systems (HCAHPS) survey. Available from: http://www.cms.gov/Medicare/Quality-I nitiatives-Patient-Assessment-Instruments/Hospita lQualityInits/HospitalHCAHPS.html

[3] Wysong PR, Driver E. Patients' perceptions of nurses' skill. Critical Care Nurse. 2009; 29(4): 24-37. PMid:19648596. http://dx. doi . org/10.4037/ccn2009241

[4] Kitson A, Marshall A, Bassett K, et al. What are the core elements of patient-centred care? A narrative review and synthesis of the literature from health policy, medicine and nursing. Journal of Advanced Nursing. 2013; 69(1): 4-15. PMid:22709336. http://dx.doi.org/10.1111/j.1365-2648.2012.06064.x

[5] Boykin A, Schoenhofer S, Valentine K. Health care system transformation for nursing and health care leaders: Implementing a culture of caring. New York, NY: Springer Publishing. 2014.

[6] Leininger MM, McFarland MR. Culture care diversity \& universality: A worldwide nursing theory (2nd Ed). London. Jones \& Bartlett Learning. 2006.

[7] Betcher DK. Elephant in the room project: Improving caring efficacy through effective and compassionate communication with palliative care patients. Medsurg Nurs. 2010; 19(2): 101-5. PMid:20476520.

[8] Blum C, Hickman C, Andrew Parcells D, et al. Teaching caring nursing to RN-BSN students using simulation technology. International Journal for Human Caring. 2010; 14(2): 40.

[9] Duffy J. Quality Caring in Nursing and Health Systems: Implications for clinicians, educators, and leaders (2nd ed). New York, NY: Springer Publishing. 2013.

[10] Porr C, Egan R. How does the nurse educator measure caring? International Journal of Nursing Education Scholarship. 2013; 10(1).

[11] Eskilsson C, Hörberg U, Ekebergh M, et al. Student nurses' experiences of how caring and learning is intertwined-A phenomenological study. Journal of Nursing Education and Practice. 2014; 4(2): 82. http://dx.doi.org/10.5430/jnep.v4n2p82

[12] Labrague LJ. Caring competencies of baccalaureate nursing students of Samar State University. Journal of Nursing Education and Practice. 2012; 2(4): 105. http://dx. doi .org/10.5430/jnep.v2n4 p105

[13] Murphy F, Jones S, Edwards M, et al. The impact of nurse education on the caring behaviours of nursing students. Nurse Education Today. 2009; 29(2): 254-264. PMid:18945526. http://dx.doi.org/10. $1016 / j$.nedt. 2008.08 .016

[14] Nadelson S. Nursing student perceptions of caring. Annual Conference of the Western Institute of Nursing, Glendale, AZ. 2010.

[15] Chickering A, Dalton J, Stamm L. Encouraging authenticity and spirituality in higher education. San Francisco, CA: Jossey-Bass. 2006.

Published by Sciedu Press members that suggest caring cannot be taught however, the evidence suggests that caring can be taught but the approach has to be student centered and meaningful.

\section{CONFlicts of InTEREST Disclosure}

The authors declare that there is no conflict of interest.
[16] Facer K. Learning Futures: Education, Technology, and Social Change. London: Routledge Publishing. 2011.

[17] Norton A, Wilson K. A longitudinal view of the liberal arts curriculum a decade after merger: A multiple case study of community colleges in Connecticut, Kentucky, and Louisiana. Community College Journal of Research and Practice. 2015; 39(7): 591-602. http://dx.doi.org/10.1080/10668926.2013.866059

[18] Brint S, Riddle M, Bicakci L, et al. From the liberal to the practical arts in American colleges and universities: Organizational analysis and curricular change. The Journal of Higher Education. 2005; 76: 2.

[19] Geiger RL. Postmortem for the Current Era: Change in American higher education, 1980-2010. In Higher education forum: a COE publication. 2013; 10: 1-21.

[20] Kuh G, Kinzie J, Schuh J, et al. Student success in college: Creating conditions that matter. San Francisco, CA: Jossey-Bass. 2005.

[21] Nadelson S, Nadelson L, Osguthorpe R. Perceptions of education, engineering, nursing faculty members regarding their role in helping students develop professional behavior. Journal of College \& Character. 2009; 10(7): 1-13.

[22] Krautscheid LC. Defining professional nursing accountability: A literature review. Journal of Professional Nursing. 2014; 30(1): 4347. PMid:24503314. http://dx.doi.org/10.1016/j.profnur s. 2013.06 .008

[23] Park SD. Big questions, worthy dreams: Mentoring young adults in their search for meaning, purpose, and faith. San Francisco, CA: Jossey-Bass. 2000.

[24] Crigger N, Godfrey N. The making of nurse professionals. London: Jones \& Bartlett Publishers. 2010.

[25] Colby A, Ehlrich T, Beaumont E, et al. Educating Citizens: Preparing America's Undergraduates for Lives of Moral and Civic Responsibility. S.F: Jossey-Bass. 2003

[26] Iacobucci TA, Daly BJ, Lindell D, et al. Professional values, selfesteem, and ethical confidence of baccalaureate nursing students. Nursing Ethics. 2013; 20(4): 479-490. PMid:23166146. http: //dx.doi.org/10.1177/0969733012458608

[27] Jukema JS, van Veelen N, Vonk R. Students experienced help from preservative care. A reflective case study of two nursing students caring from a nursing framework on good care for older people. International Practice Development Journal. 2015; 5(2): 6.

[28] Larrivee B. Creating caring learning communities. Contemporary Education. 2000; 71(2): 18-22.

[29] Watson J. Caring Science. 2013.

[30] Porr C, Egan R. How does the nurse educator measure caring? International Journal of Nursing Education Scholarship. 2013; 10(1): 35-43.

[31] Gonzalez R, Pietsch TT, Kozub K, et al. Caring: Looking beyond simulations. International Journal for Human Caring. 2010; 14(2): 15.

[32] Whittemore R, Knafl K. The integrative review: Updated methodology. Journal of Advanced Nursing. 2005; 52(5): 546-553. 
PMid:16268861. http://dx.doi.org/10.1111/j.1365-2648. 2005.03621.x

[33] Watson J. Core concepts of Jean Watson's theory of human caring/caring science. 2014. Available from: http://watsoncaringscience.org/files/Cohort $\% 206$ /watsons-theory-of-human-caring-core-concepts-and -evolution-to-caritas-processes-handout.pdf

[34] Adamaski M, Parsons V, Hooper C. Internalizing the concept of caring: An examination of student perceptions when nurses share their stories. Nursing Education Perspectives. 2009; 30(6): 358-361. PMid:19999936.

[35] Chan EA, Mok E, Po-ying AH, et al. The use of interdisciplinary seminars for the development of caring dispositions in nursing and social work students. Journal of Advanced Nursing. 2009; 65(12): 2658-2667. PMid:19941549. http://dx.doi.org/10.1111/j.1 365-2648.2009.05121.x

[36] Eggenberger T, Keller K, Locsin RC. Valuing caring behaviors within simulated emergent nursing situations. International Journal for $\mathrm{Hu}-$ man Caring. 2010; 14(2): 22.

[37] Minnesota Baccalaureate Psychomotor Skills Faculty Group. Nursing student caring behaviors during blood pressure measurement. Journal of Nursing Education. 2008; 47(3): 98-103. PMid:18380262. http://dx.doi.org/10.3928/01484834-20080301-06

[38] Panosky D, Diaz D. Teaching caring and empathy through simulation. International Journal for Human Caring. 2009; 13(3): 44.

[39] Curtis MP, Jensen A. A descriptive study of learning through confluent education: an opportunity to enhance nursing students' caring, empathy, and presence with clients from different cultures. International Journal for Human Caring. 2010; 14(3): 48
[40] Drumm J, Chase SK. Learning Caring: The Student's Experience. International Journal for Human Caring. 2010; 14(4): 31.

[41] Letcher DC, Nelson ML. Creating a Culture of Caring: A Partnership Bundle. Journal of Nursing Administration. 2014; 44(3): 17586. PMid:24531291. http://dx.doi.org/10.1097/NNA.00000 00000000047

[42] Ozolins LL, Elmqvist C, Hörberg U. A nursing student-run health clinic - an innovative project based on reflective lifeworld-led care and education. Reflective Practice. 2014; 15(4): 415-426. http: //dx.doi.org/10.1080/14623943.2014.900024

[43] Schofield R, Allan M, Jewiss T, et al. Knowing self and caring? International Journal of Nursing Education Scholarship. 2013; 10(1).

[44] Stewart Hegedus K, Espelin J, Griffiths LM, et al. Developing and sustaining a study abroad program as viewed through a caring lens. International Journal for Human Caring. 2011; 15(3): 67.

[45] McGarry J. Defining roles, relationships, boundaries and participation between elderly people and nurses within the home: an ethnographic study. Health \& Social Care in the Community. 2009; 17(1): 83-91. PMid:18700870. http://dx.doi.org/10.1111/j.1365-2524. $2008.00802 . \mathrm{x}$

[46] Waugh A, Donaldson J. Students' perceptions of digital narratives of compassionate care. Nurse Education in Practice. 2016; 17: 22 29. PMid:27038084. http://dx.doi.org/10.1016/j.nepr. 20 16.01 .008

[47] Parrish DR, Crookes K. Designing and implementing reflective practice programs-Key principles and considerations. Nurse Education in Practice. 2013: 1-6. 